\title{
体育学習におけるパーソナルコンピュータ利用の展望と課題
}

\author{
賀川 昌明
}

\section{Review and proposal regarding the use of personal computers for physical education}

\author{
Masaaki Kagawa
}

\begin{abstract}
The present paper reviews the effects and problems associated with the use of personal computers in physical education, and seeks more effective methods of use for this purpose. First, previous reports about computer use in physical education were divided into the two categories: Measurement and Assessment, and Computer-assisted Instruction or Computer-assisted Learning. Second, reports belonging to the two categories were reviewed, and checked from the viewpoint of using effects verification. Finally, the potential and the noteworthy points were discussed in relation to future use of computers in physical education. The results obtained through these steps are summarized as follows; 1 . Many kinds of application software have been developed and used in physical education, but there are few reports in which strict verification of the effects has been discussed. Although limited in extent, effects at a cognitive level have been suggested in physical education classes for primary and junior high school children, and effects on knowledge acquisition and motor skill acquisition have been suggested in physical education classes for high school and college students. 2 . For future effective use of computers in physical education, stricter verification of the effects through practical study involving qualitative analysis or case studies, introduction of new techniques, and adequate consideration of relevant problems are necessary.
\end{abstract}

\section{Key words : physical education class, practical study, CMI, CAI, effect of using} (Japan J. Phys. Educ. Hlth. Sport Sci. 51: 409-419, July, 2006)

\footnotetext{
鳴門教育大学学校教育学部 ₹ 772-8502 徳島県鳴門市鳴門町高島字中島 748 番地 連絡先 賀川昌明
}

Naruto University of Education, Faculty of School Education

748, Aza-Nakashima, Takashima, Naruto-cho, Narutoshi, Tokushima-ken, 772-8502

Corresponding author kagawama@naruto-u.ac.jp 
キーワード: 体育授業, 実践研究, CMI, CAI, 使用効果

\section{Iはじめに}

1999 年 12 月，文部省は「ミレニアム・プロジ エクト」を発表し, その中で「教育の情報化」に 関連して次のような構想を打ち出した（文部省学 習情報課，1999）。

(1)全ての公立小中高等学校, 盲・万う・養護学 校がインターネットに接続できるようにする (2001年度目標). (2)全ての公立小中高等学校等 が，各学級の授業においてコンピュー夕を活用で きる環境の整備を行えるようにする（2005年度 目標)。(3)公立小中高等学校等が, 校内ネットワ ーク（LAN）機能の整備を行えるようにする (2004年度目標). (4)全ての公立学校教員がコン ピュータの活用能力を身につけられるようにする (2001 年度目標)。(5)学習資源を活用した学校教 育用コンテンツの開発，成果の普及を図る（2005 年度目標)。

さらに 2000 年 7 月，国際的に競争力のある 「IT (Information Technology) 立国」の形成を 目指した施策を総合的に推進するため, 内閣に 「情報通信技術（IT）戦略本部」を設置するとと もに，20名の有識者から構成される「IT 戦略会 議」を設置した。2 001 年 3 月にはIT 戦略本部に おいて「e-Japan 戦略」および「e-Japan 重点計画」 が策定され，「世界最高水準の高度情報通信ネッ トワークの形成」,「教育及び学習の進行並びに人 材の育成」，「電子商取引等の促進」，「行政の情報 化及び公共分野における情報通信技術の活用の推 進」,「高度情報通信ネットワークの安全性及び信 頼性の確保」等の項目が掲げられ，教育に関する IT 化にも重点的な予算配備が行われた（IT 戦略 本部, 2001).

その結果, 平成 16 年度における 1 学校あたり の教育用コンピュータ平均設置台数は 43.2 台（小 中高等学校, 盲・万う・養護学校による. 以下, 同じ）となり，教育用コンピュー夕 1 台あたりの 児童生徒数は 8.1 人となっている. また，学校の
インターネット接続率は $99.9 \%$ となり, 普通教室 の LAN 整備率も $44.3 \%$ とっている. しかしな がら，こういったコンピュータで指導できる教員 の比率は約 $68.0 \%$ あ゙あり, コンピュー夕を操作で きる教員の比率約 $94.9 \%$ に比べるとかなり低くな っている（文部科学省, 2005a).

一方，2002 年度から完全実施されている小・ 中学校学習指導要領および 2003 年度から完全実 施されている高等学校学習指導要領においても, 各教科や総合的な学習の時間でのコンピュータや 情報通信ネットワークを活用することが謳われて いる，それと同時に，国や都道府県においてはコ ンピュータ操作技能を教員に習得させるため, 各 種の研修を実施してきた。また，国のモデル開発 指定によって各種のデジタル・コンテンツを開発 するとともに，それらを使用した授業実践例を公 開してきた（文部科学省，2005b）.

その結果，体育授業を対象とした様々なデジ夕 ル・コンテンツが開発され, それらを使用した授 業実践例も報告されているが，他の教科に比べる とまだ少なく，その種類も限られたものになって いる．例えば，教育情報ナショナルセンターのホ ームページ（http://www.nicer.go.jp/）に登録さ れた教師用デジタル・コンテンツの数を見ても， 体育・保健体育関係のものは全体の約 $7 \%$ あ゙あ り，ほとんどがモデルとなる動きのクリップ（大 きな動画ファイル中の小さな断片) で構成されて いる. また，その実践例の多くがそれらの使い方 に対する説明であり, その使用効果を実証的に提 示したものは少ない。しかしながら，これからの 情報化社会に対応するためには，体育学習におい てもコンピュータの持つ機能を積極的に利用する ことが求められる。また，体育の授業時間数が削 減された昨今においては，体育授業の機能を最大 限に発揮するためにも，それらの有効利用が望ま れるところである。

本稿においては，このような視点から体育学習 におけるパーソナルコンピュータ（以下，パソコ ンとする）利用に関わる研究報告や実践報告を紹 介し，そこに示された成果と問題点を検討する中 から，今後の展望と課題とを探ることにする。な 
お，今回は体育授業の実践に関わるものを対象と

し, 授業分析等の研究手法に関わるものは除外し た.

\section{II 教育におけるパソコン利用}

教育におけるパソコン利用の典型例として挙げ られるものに次の 2 つがある。ひとつは CMI (Computer Managed Instruction) と呼ばれるも ので，いわゆるパソコンによる教育情報の管理・ 運用を指す，例えば，各種テストや調査・測定の 結果をデータベースとして保存し，それらから判 定基準を算出して学習者の評価に利用するなどの 方法がそれに当たる。もうひとつは，CAI (Computer Assisted Instruction) と呼ばれるも ので，パソコンによる学習支援を指す．過去にお いては典型的なプログラム学習理論に基づくチュ ートリアル型の教授方法を指すことが多かった が, 現在では学習者が自分の特性にあった情報を 選択して利用するという，いわゆる主体的学習支 援を意図したデータベース型のものも含まれるよ うになった。 また, 最近では学習活動に焦点を当 てたCAL (Computer Assisted Learning) とい う用語が使われることも多い.しかし, CMI と して作成されたデータも使い方次第ではCAIや CALともなりうる。そのため, CMI - CAI • CALなどを統合した，教育におけるコンピュー 夕利用のすべてを含む用語として CITL（Computer Integrated Teaching and Learning) も使 われるようになっている（岡本，1999）。

\section{III 体育学習におけるパソコン利用}

体育学習におけるパソコン利用の方法も, 基本 的には上に述べたものが当てはまると言えよう。 しかしながら，体育館やグラウンドにおける身体 活動を中核として授業が成立している体育学習の 場合，その利用に関しては他教科と少々条件が異 なってくる.

例えば, Silverman（1997）は体育学習におけ るパソコン利用の方法として, (1)ユーティリティ
一, (2)測定・評価, (3)学習支援の3つをあげてい る.このうち，11ぱソコンのワープロソフトを 利用して行う学習指導案や宿題, テスト問題, 学 習資料のプリント作成等がそれにあたり，他教科 における利用方法と大差が無い。しかし, (2)や(3) はCMI・CAI・CALの範疇に入るもので, 体育 学習特有の利用方法が存在する。すなわち, (2)の 測定・評価では知識・態度のみならず, 運動技能 や体力も対象となる. また, (3)の学習支援に関し ては, 運動の仕組みや原理の理解, さらには練習 方法や技術ポイントの理解等, 身体活動と並行し た形でのパソコン利用が必要となる.

以下，これらの分類に基づき，体育学習におけ るパソコン利用に関わる研究報告のうち, 主に(2) 測定・評価と(3)学習支援に関するものに焦点を当 てて検討することにする。

\section{1. 測定・評価に関わるパソコン利用}

体育・スポーツ分野におけるパソコンの使用 は, 運動に関わる様々な変数の測定や分析から始 まっている．例えば運動に際して発現する体内変 動の生理・心理学的デー夕を処理したり（Donnelly, 1987 ; Mathes and Engelhorn, 1987), 運動実施状況の録画画面から各局面における身体 部位の移動や変化を用いて力学的指標を計算した りするもの（Richards，1987；山田ほか, 1987 ; 藤井，1998）がそれに当てはまる。これ らの方法は生理・心理学的デー夕採取や画像録画 に当たって高価な機器が必要であったこと, その 分析に際しても高度な知識・技術や機器が必要だ ったこともあって，一般的な体育授業において使 用されることは少なかった. しかしながら, 近年 の技術進歩と機器の低廉化により，このような手 法を体育学習に取り入れる試みも見受けられるよ うになっている。例えば，布目（2001）や増田・ 近藤（2002）は対象となる運動の分割映像を提示 し, その各局面における技術ポイントを学習者に 理解させようとしている.

一方，体力テストや運動技能テストのデータを パソコンに入力し,それらを統計的に処理したり, そこから算出された基準值によって標準化された 
值をグラフ化したりするという試みは，比較的早 い段階から一般的な体育授業においても取り入れ られてきた。例えば, Strand and Mathesius (1995) やStrand and Reeder (1993a, 1993b) は中学校の体育授業において心拍数を指標として 自分の体力を評価するという試みを行っている。 平田（1971）は小・中・高・大学生を対象とした 体格体力判定基準を作成して体育授業における活 用を提案し，野崎（1992）は中学校体育授業にお いて体力テストの結果をマークシートリーダーで 入力する試みを報告している。また，橋本・山形 （1989）は小学校における持久走を対象に，その 記録の一覧やグラフをパソコンで作成する試みを 報告している。ささら杉山（1990a）はパソコン の計時機能を利用して，中学校体育授業の短距離 走における記録測定を試みている。

その他, 各種ゲームの結果や試合展開をパソコ ンで分析し，その結果を次のゲームに活かそうと する試みも行われてきた（勝本ほか，1994；山 中・梁，1993；山中ほか，1994；小山ほか, 1998）。そして，このような使い方は体育授業に おいても利用されるようになり，小学校体育授業 における高村（1994）や中学校体育授業における 小山（1999），北野（1999）, 山本ほか（2003a） などの実践報告があるが，いずれもボール運動を 対象としたものが多い.

\section{2. 学習支援に関わるパソコン利用}

体育学習を指導する教師にとって最も関心が高 かったのは，対象となる運動のイメージや技術的 ポイントを学習者に対してどの様にして把握させ るかということであった。 そのために必要な教示 や示範の仕方に関する工夫が数多くなされたが, それらを補足するものとして古くは説明図，写真 等の静止画が用いられた。これらの方法は，体育 授業の場における物理的制限もあり，その提示画 像もある特定場面に限らざるを得なかった。した がって，そこで提示される情報がすべての学習者 に該当するものとは限らなかった。

これらの欠点を解消すべく工夫されたのが，学 習者の「できばえ」や「つまずき」に対応した説
明を静止画像とともにパソコンで提示する CAI ソフトの開発である。賀川・福良（1993）は，小 学校マット運動を対象に児童が自分の「できばえ」 から「つまずき」を探り出し，それらに対応する 技術ポイントや練習方法の説明を静止画像ととも に提示するソフトを開発し，授業実践を行ってい る.

また，動きのイメージを把握させるため， $16 \mathrm{~mm}$ あるいは $8 \mathrm{~mm}$ フィルム，ビデオによる動 画の提示も頻繁に使用された。これらはダイナミ ックに変化する各局面の状況を理解させるには効 果的であったものの, 当該デー夕を提示するまで に巻き戻し作業が必要という点で体育授業での使 用には問題があった。

そこで，これらの問題を解決するために工夫さ れたのがパソコンによるコンセプトフィルム（数 分程度の短い映像を繰り返し映写する機器）やビ デオ制御という方法である。例えば，向出（1990） は小学校マット運動においてパソコンとコンセプ トフィルムとを組み合わせた「つまずき対応」の CAIソフトを作成し，授業実践を行っている. また，見米ほか（1991）は小学校跳び箱運動にお いてモデルとなる動きをパソコン制御によるビデ オによって提示し，それぞれのつまずきに対する 静止画像をパソコン画面に提示している，いずれ も該当する動画を巻き戻し作業なしで提示できる という点では $16 \mathrm{~mm}$ あるいは $8 \mathrm{~mm}$ フィルム，ビ デオの持つ欠点を補うものであった.

しかしながら，こういった工夫も次の段階で生 じたパソコンの動画処理機能の飛躍的発展によっ てその影を潜めることになる。つまり，ビデオ画 像をパソコンに取り込んで動画クリップ化すると いう技術により，見たい動画が巻き戻し作業なし に提示されるようになったわけである。これを契 機として，体育授業での使用を想定した数多くの 学習支援ソフトが作成されるようになった。例え ば，北川（1994）は小学校鉄棒運動を対象とした 動画提示ソフトを開発し，賀川・石井（2000）も 前述の小学校マット運動を対象としたマルチメデ イア教材のソフトを作成している。また，佐々 木・マングカング (2002) は小学校器械運動領域 
における跳び箱・マット運動・平行棒を対象とし たタイ国用マルチメディア教材を作成している. さらに, 安藤ほか（2004a）は小学校表現運動を 対象としたマルチメディア教材を作成し，授業実 践を行っている。このように，この種のソフトは 器械運動や表現運動のような個人的種目を対象と したものが多いが，小学校フラッグフットボール を対象とした山本ほか（2003b）や中学校バレー ボールを対象とした賀川・井川（2000）のように， ボール運動における基本的技能の理解に焦点を当 てたものもある. その他, 大学体育授業における スキー指導を対象としたソフトの開発（野田， 1999）も見受けられる.

以上のように体育授業における学習支援に関わ るパソコンの利用方法としては, 音声を含む動画 クリップと文章による説明とをリンクさせた，い わゆるマルチメディアという形で運動のイメージ を掴ませたり，学習者のつまずきに応じた技術ポ イントや練習方法を提示したりすることによって 運動学習を効果的に行㧍うとするものが多い.し かしその一方で, ルールや練習方法, さらには体 の仕組み等に対する知的理解を促進するために開 発されたものもある。例えば，杉山（1990b）は 中学校陸上競技における練習方法とルールを理解 させるためのソフトを開発し, 根本ほか（1995） は筋肉や骨の名称理解度をテストするソフトを開 発している。このようなパソコン使用方法は保健 分野でも数多く行われており，エイズの授業（小 磯ほか，1998，1999）や薬物乱用防止教育の授業 （小磯ほか，2001）の報告がある.

\section{3. 体育学習におけるパソコン使用効果}

以上に述べたとおり，体育学習におけるパソコ ン使用の形態には様々なものがある。そしてそれ らは，インターネットの普及とともに驚異的な広 がりを見せている。しかしながら，それらの大部 分はソフトの概要や使い方についての紹介が中心 であり, その使用効果に対する吟味は, 必ずしも 十分ではない. 以下，このような視点から，ソフ トの使用効果について触れている報告を中心に紹 介することにする。
まず，小学校における授業実践報告から見てみ ることにする．賀川・田村（1998）はマット運動 を対象に作成された「モデル提示型ソフト」と 「つまずき提示型」ソフトを使用した授業実践を 行ったが，実施時間数が少なかったこともあって 明確な違いは見出せなかった. 増田・近藤 (2002) は跳び箱運動を対象とした動作分析システムを使 用した授業実践を行い, 意欲, 問題解決能力, コ ミュニケーション能力, 技能の育成において成果 が得られたとしている。山本ほか（2003c）も跳 び箱運動を対象とした動画コンテンツを体育授業 において使用した場合に，児童が自らの課題を明 確化する上で効果があるとしている，さらに，賀 川・石井（2000）や賀川・湯口（2000）もマット 運動を対象としたソフトを体育授業で使用し，そ れによって「めあての内在化」や「コミュニケー ションの促進」が図れるとしている. また, 安藤 ほか（2004b，2005）は小学校低学年を対象とし た表現リズム遊び支援ソフトによる授業実践を行 い, 低学年でもパソコン使用が可能なこと, ソフ 卜使用によって表現の広がりが見られることを報 告している.さらに, 山本ほか $(2003 b)$ は小学 校フラッグフットボールの指導においてボールの 投げ方を中心としたソフトを使用し, 実験群は対 照群よりも有意に高い的当て得点を示したが，遠 投力においては有意差が認められなかったことを 報告している.

中学校における実践では，小磯ほか（1999, 2001）が保健におけるエイズ教育や薬物乱用防止 教育を対象とした授業を行い, 生徒の知識向上に 役立ったと報告している。また，山本ほか (2003a）はハンドボールの授業におけるチームプ レイ指導のためのソフトを作成して使用した結 果, グループの学習には差が見られなかったもの の, 主体的に作戦や練習方法を考えようとする傾 向が認められたと報告している。ささらに, 安藤ほ か（2004c）は表現運動における作品の構成と創 作手順を示すソフトを作成して授業実践を行った 結果，生徒からソフトを使った授業の方が分かり やすいという評価を得たと報告している.

このように, 小・中学校体育授業を対象とした 
実践では, 児童の学習意欲や学習課題の把握, 技 術的ポイントや学習方法の理解等に効果があると いう報告が多い。しかしながら，これらは児童の 自己評価や教師の観察等から導き出されたものが 多く, 実際の知識習得や技能獲得を実証する形の ものは少ない。この原因として, 現在のわが国に おける教育事情からすると，実験群と統制群の設 定といった実験的手法に基づく授業実践計画が組 みにくいこと，現段階ではパソコンを使った授業 実践を行うのに手一杯で，その効果を実証するデ 一夕採取まで手が回らないこと等が考えられる。

一方，諸外国では大学生や高校生を対象とした 実践ではあるが，体育授業において実験的な手法 に基づく研究報告が見られる。例えば，Boysen and Francis（1982）は大学でのバイオメカニク スの授業を対象にワークシートとコンピュータソ フトによる学習を比較し, コンピュータソフトに よる学習群の動作の力学的分析テスト成績が有意 に高い得点を示したことを報告している。また， Steffen and Hansen（1987）は大学のボーリング 授業に参加した 90 名の学生を伝統的な指導クラ スとCAIによるクラスとに分割し, 知覚運動ス キル, 標準化された得点, 学生の認識を比較して いる。その結果，ボーリングのスコアはCAIク ラスが有意に高かったが，知識テストには差がな かった。また，授業評価はCAIクラスが高くな る傾向が認められたと報告している。さらに， Adams and Kandt（1991）は大学におけるゴル フ初心者クラスの学生を対象に, ゴルフルールに 対する知識習得について CAI と従来の講義によ る指導効果を比較した。 その結果, ゴルフ知識に 対する有意差はなく，より一層の検討を要すると 報告している. Wilkinson and Hiller（1999）は 69 名の女子高校生を対象に実験群と統制群に分 割したバレーボールの授業実践を行っている。実 験群では各技能のモデルを多角的に動画で提示す るとともに文字や音声で解説し, クリックによっ て利用者が必要な部分を提示可能な CD-ROMを 使用した. 分析の結果, 実験群ではアンダーハン ドパスで有意な向上がみられ，ゲーム中のセット アップ数が有意に多かった。また $75 \%$ の者が自
分の技能が向上したと答え， $84 \%$ 者がルール の理解に役立ったと答えたと報告している.

以上のことからすると, 少なくとも小・中学生 を対象とした実践では児童・生徒の意識レベルに おける効果が認められ，大学生や高校生を対象と した授業実践では知識習得や技能習得にも効果が 認められる可能性が大きいと考えられる.しかし， 厳密な意味では効果を検証されていない部分も多 く, 今後, 質的分析や事例研究の手法を取り入れ た授業実践を行い，より明確な検証を行う必要が あるように思われる。

\section{IV これからの展望}

以上，体育学習を支援するためのパソコン使用 方法やその効果について概観してきた. 次に，こ れらの結果も踏まえながら，まだ体育授業での導 入実績は少ないものの, これからの活用が期待で きる項目について触れることにする。

\section{1. シミュレーション (Simulation) モデルの 開発}

シミュレーションとは, ある特定の運動や事象 に関与する各種の要因をモデル化し，それぞれに 適切な数值を代入することによって結果の最適化 を図ろうとする試みである。すでにバイオメカニ クスの分野では数多くの研究報告がなされている （藤井，1998）が，体育授業を対象に行われたも のは少ない，今後，体育授業における使用を想定 したモデルが構築されることにより，より効果的 な学習が期待できるものと思われる.

\section{2. デジタルポートフォリオ（Digital Portfo- lio）の活用}

従来, 学習者の成果を評価する場合, 運動技能 テストや知識テスト等, 結果を数量化できるもの の利用が多かった. しかしながら, 結果として現 れた量的変化だけでなく, 内面での質的な変化や その過程などをも評価の対象として考えること は，学習者の意欲を喚起する上で，また本質的な 学習を成立させる上でも重要なことである。「総 
合的な学習の時間」で盛んに使用されるようにな ったデジタルポートフォリオは，そのような観点 での効果が期待できる. デジタルポートフォリオ とは, 学習の各種情報を一種の絵日記方式でパソ コンに記録するものであり，そこには今までに行 つた作業課題やその結果, 学習者の感想等が保存 される，体育学習の場合, パソコンを使うことに よって学習各時点における運動実施状況を動画と して保存することも可能となり, 学習者にとって も教師にとっても有益な資料となりうる.

\section{WBT (Web Based Training) および e- learning (遠隔教育) システムの構築}

本稿においては, 印刷物として公表された研究 報告や実践報告を中心に検討してきた。一方，体 育学習に利用できる情報は他にも数多く発信され ており，インターネットを通じて簡単にウェブ上 の情報が手に入るようになっている，ただ，現在 においては，その有効性や信憑性という点で必ず しも裏づけのあるものばかりとは限らないため, 安易な利用を勧めるわけにはいかない.しかし, その裏づけさえできれば，学習者が安心して自宅 や図書館等から予習や復習のために活用すること が可能となる。このような WBT や e-learning シ ステムの構築は, 体育学習を自己ペースで個別的 に進める上で有効な手段となりうる.

\section{4. 体育学習支援から教師教育支援へ}

体育学習におけるパソコンの利用は，まず教師 が自分の事務処理を支援する目的からスタートし た。その結果，授業で配布する資料の作成や各種 デー夕整理に要する労力が大幅に軽減された。そ れらは広い意味では学習者の支援にもつながった が, 直接的な学習支援はいわゆるパソコンの CAI的使用から始まる。そして，さまざまなソ フトや手法が開発され，それらを授業実践の中で 使用するうちに，それらが教師の教材解釈や授業 構成力の育成にも役立つことが判明した. 我が国 においては，このような視点からの研究報告はま だ少ない（賀川，2004）が，諸外国においては 様々な研究報告がなされている（Adams and
Waldrop, 1985 ; Sariscsany and Pettigrew, 1997 ; Mitchell and Hunt, 1997 ; McKethan et al., 2000 ; McKethan and Everhart, 2001 ; Bailey and Parker, 2004). 今後, このような教 師教育に関わる研究が進むことによって, さらに 充実した体育学習支援が実現するものと思われ る.

\section{V 今後の課題}

今までの体育学習におけるパソコン利用は, 「測定・評価」に関わるものと「学習支援」に関 わるものとに分かれる. そのうち「学習支援」に 関わるものの大半は, 運動技能習得に資する「運 動イメージ」獲得を意図したものとなっている。 すなわち, 学習対象となる運動のモデルやつまず き場面を動画や文字とともに提示することによっ て，その技術的ポイントや練習方法に対する理解 を図ろうとするものである。その結果, 学習意欲 の喚起, 技術的ポイントや練習方法の理解に効果 があるという報告は多いものの，それらが技能向 上にも寄与するという研究報告はそれほど多くな い。また，体育学習において習得すべき内容には， 前述の運動技能だけではなく, 態度や学び方も含 まれている。したがって，体育学習におけるパソ コン利用を考える上では，これらを統合的にとら えた「学習支援ツール」としての利用方法を検討 すべきであろう。

以下，このような観点から検討すべき事項につ いて簡単に触れ, 筆者の今後の研究指針としたい.

1）ソフトの内容吟味と精選・整理

数年前と違い, 現在ではインターネット上に公 開されているソフトだけでもかなりの数に上る. その中には上に述べた観点から問題を含んでいる ものや，体育学習において使用するには不適切な ものもある。それらを十分に吟味して取捨選択し， 真に体育学習に役立つものを精選し整理する必要 がある。

2）体育学習に関わるIT 環境の整備

体育学習におけるパソコン使用を想定した体育 施設はまだ少ない。しかし，体育学習において効 
率的にパソコンを利用するためには，体育施設全 体にパソコン本体やその周辺機器が簡単に利用で きる環境を整える必要がある。

3）パソコン使用効果の検証

前項の課題を達成する上で不可欠な手順とし て，パソコンを使用することによって体育学習の 目的に沿った効果が実現可能なのかどうかを検証 する必要がある。低廉化が進んだとは言え，まだ 高価な機材が多い。体育施設にIT 環境が整うか どうかは，その整備に要する経費やソフト作成の 労力と使用効果との兼ね合いで決まることを認識 し，授業実践を通じた使用効果の検証を推進した い.

4）利用方法に関わる研修と研究の推進

上に述べた各項目がクリアできたとしても，そ れらを効果的に使いこなすかどうかは教師の技量 にかかっている．何もかもパソコンに任せてしま うのでは，体育学習の目的から外れることになり かねない。パソコンの操作法は無論のこと, ソフ 卜の内容を生かす使い方や学習者の意識づけ等, パソコンを使った体育授業の効果的展開方法に関 する研修や研究を今以上に進める必要がある。

5）情報のデータベース化

最後に，本稿でふれたソフトやパソコンの使い 方等を含め，体育学習におけるパソコン利用に関 わるすべての情報をデータベース化することを検 討したい。前述の教育情報ナショナルセンターホ ームページでは，教育におけるIT利用の実践例 を「“IT授業”実践ナビ」という形で公開してい る、しかしながら，ここではかつて文部科学省が 支援して行ったプロジェクト報告が中心となって おり，トータルな形でのデータベースとはなって いない。今後，研究者や学校現場，教育行政機関 をも含んだ共同作業によって，授業実践に役立つ 統合的データベースの作成が望まれる.

\section{文献}

Adams, II, T.M., Kandt, G.K., Throgmartin, D., and Waldrop, P.B. (1991) Computer-assisted instruction vs. lecture methods in teaching the rules of golf. Physical Educator, 48: 146-150.
Adams, II, T.M. and Waldrop, P.B. (1985) Computer assisted instruction in teacher education. Physical Educator, 43: 156-160.

安藤 幸. 賀川昌明 - 安田哲也 - 岡田晶子 - 漆原和 美・木下奈津子（2004a）体育学習を支援する「学 習支援ソフト」の開発：表現リズム遊び「どうぶ つランド」を事例として。鳴門教育大学研究紀要, $19: 5-14$.

安藤 幸. 賀川昌明 - 木原資裕 - 藤田雅文 上田憲 嗣・安田哲也・漆原和美 - 三戸治子（2004b）体育 学習を支援するデジタル教材の開発と評価（第 4 報）：表現リズム遊び「どうぶつランド」の授業実 践 1. 鳴門教育大学研究紀要, $20 ： 1-11$.

安藤 幸 - 賀川昌明 - 木原資裕 - 藤田雅文 - 松井敦 典・棟方百熊・上田憲嗣（2004c）体育授業におけ る「学習支援ソフト」の使用効果についての検討 (第 1 報)：中学校ダンス指導における試み. 日本教 科教育学会誌, 16 (4) : 19-28.

安藤 幸 - 賀川昌明 - 木原資裕 - 藤田雅文 $\cdot$ 上田憲 嗣・安田哲也・漆原和美（2005）体育学習を支援 するデジタル教材の開発と評価（第 5 報）：表現リ ズム遊び「どうぶつランド」の授業実践 2 . 鳴門教 育大学実技教育研究, $15 ： 27-38$.

Bailey, J. and Parker, M. (2004) Use of web-based learning system as a resource for cooperating teachers. Research Quarterly for Exercise and Sport, (March Supplement): A-57.

Boysen, J.P. and Francis, P.R. (1982) An evaluation of the instructional effectiveness of a computer lesson in biomechanics. Research Quarterly for Exercise and Sport, 53: 232-235.

Donnelly, J.E. (1987) Microcomputer applications in exercise physiology. In: Donnelly, J.E. (Ed.) Using microcomputers in physical education and the sport sciences. Human Kinetics: Champaign, pp. 187-209.

藤井範久（1998）バイオメカニクスにおけるコンピ ユータシミュレーション. 体育学研究, $42 ： 394-$ 400.

橋本 高・山形積治（1989） 日常的な体育指導にお けるパソコンの利用. 北海道教育大学 CAI 研究報 告, $17: 103-122$.

平田欽逸（1971）コンピュータによる体格体力判定 法とその実用成績. 体育学研究，15（5）：141. 
IT 戦略本部（2001）e-Japan 重点計画概要．http:// www.kantei.go.jp/jp/singi/it2/kettei/01329gaiyou. html

賀川昌明・福良正典（1993）小学校体育授業におけ るCAI導入に関する研究：マット運動への適用と その効果についての検討. 鳴門教育大学学校教育 研究センター紀要, 7 : 125-135.

賀川昌明・田村晃子（1998）体育授業を支援するマ ルチメディア情報の提供に関する研究：「モデル提 示型ソフト」と「つまずき提示型ソフト」の作成 とその効果について。鳴門教育大学学校教育研究 センター紀要, $12 ： 13-19$.

賀川昌明・井川 浩 (2000) 中学校体育授業用マル チメディア型学習支援ソフトの開発。鳴門教育大 学学校教育実践センター紀要, $15 ： 51-55$.

賀川昌明・石井源信（2000）マルチメディア型マッ 卜運動学習支援ソフトの開発と小学校体育授業で の試用. 日本教育工学雑誌, $24: 29-34$.

賀川昌明・湯口雅史（2000）小学校体育授業におい て「生きる力」をどのようにして育てるか：コン ピュータソフト利用によるめあての内在化とコミ ユニケーション行動の促進を通して。学校体育, $53(10): 40-45$.

賀川昌明（2004）小学校教師用マット運動指導力向 上支援ソフトの開発。日本教育工学会論文誌, $28: 21-24$.

勝本 真・吉田雅行・岡部修一 (1994) バレーボー ルのスカウティングシステムの開発（3）: コンピ ユータシステムの改良. 茨城大学教育学部紀要, $43: 85-93$.

北川 隆（1994）パソコンを使った体育授業の実践 例 - 鉄棒運動の授業 (小学校)。体育科教育, 42 (11) : 37-40.

北野恵一（1999）コンピュータを活用した体育科学 習指導：バスケットボールにおける課題解決学習 を通して。学校体育，52（6）：64-67.

小磯 透・小山 浩・中村な抢み（1998）マルチメ ディアによるエイズの授業. 筑波大学附属中学校 研究紀要, 50 : 113-132.

小磯 透 · 鈴木和弘 · 大津清二 · 笠井直美 - 石川哲 也 ·勝部眞吾 · 渡邊正樹 · 吉田勝美 (1999) 中学 校保健のエイズの授業における教育効果に関する 教育実験的研究：マルチメディア（CD-ROM）を 用いた授業とVTRを用いた授業における知識に関
する教育効果の比較検討. 学校保健研究, $41 ： 153$ -167 .

小磯 透 - 小山 浩 - 中村なお · 内田匡輔 · 入江 康平・福原圭子・伊藤 隆・鈴木和弘 - 高石昌 弘・大澤清二・齋藤 実 (2001) マルチメディア （CD-ROM）による薬物乱用防止教育の授業. 筑波 大学附属中学校研究紀要, 53:35-51.

小山 浩・大西武三・村松 誠 (1998) コンピュー 夕を利用したゲームデータ処理システムについ て: '97ハンドボール世界選手権熊本大会での処理 システム。筑波大学附属中学校研究紀要, 50： 133-153.

小山 浩（1999）パソコンを利用した授業でのゲー ム分析について. 筑波大学附属中学校研究紀要, $51: 51-64$.

増田正治・近藤 勲（2002）動作分析システムを援 用した小学校体育の授業改善の試みとその分析結 果：跳び箱運動の指導をもとに. 日本教育工学会 研究報告集, pp. 81-86.

Mathes, S. and Engelhorn, R. (1987) Microcomputer applications in sport psychology. In: Donnelly, J.E. (Ed.) Using microcomputers in physical education and the sport sciences. Human Kinetics: Champaign, pp. 211-233.

McKethan, R., Everhart, B., and Stubblefield, E. (2000) The effects of a multimedia computer program on preservice elementary teachers' knowledge of cognitive components of movement skills. Physical Educator, 57 (2): 58-68.

McKethan, R. and Everhart, B. (2001) The effects of multimedia software instruction and lecture- based instruction on learning and teaching cues of manupulative skills on preservice physical education teachers. Physical Educator, 58 (1): 2-14.

見米 宏 · 大中 勲 - 廣瀬瑞光 (1991) 小学校体育 におけるパソコン利用. 日本科学教育学会第 15 回 年会報告集, pp. 519-522.

Mitchell, D.L. and Hunt, D. (1997) Multimedia lesson plans- help for preservice teachers. Journal of Physical Education, Recreation, and Dance, 68 (2): $17-20$.

文部省学習情報課（1999）「ミレニアム・プロジェク ト」により転機を迎えた「学校教育の情報化」: 「総合的な学習」中心から「教科教育」中心へ. 文 
部省配付資料, pp. 1-18.

文部科学省（2005a）学校における情報教育の実態等

に関する調查結果. http://www.mext.go.jp/

b_menu/houdou/17/08/05080101.htm

文部科学省（2005b）情報化への対応. http://www. mext.go.jp/a_menu/shotou/zyouhou/main18_a2.htm 向出 章 (1990) マット大将 (小学校, 高学年, 体 育分野「器械運動」分野). 堀口秀嗣監 FCAI実 践シリーズ, 教科編/保健体育. 文溪堂: 東京, pp. $31-49$.

根本昌樹・鈴木三男・根本信行 - 坂本 智 (1995) マルチメディアによる保健体育教育の実践. 福島 保健体育学研究, $6: 1-8$.

野田雄二（1999）マルチメディア教材を活用した体 育教授支援システムの可能性. 玉川学園・玉川大 学体育・スポーツ科学研究紀要, $1: 52-55$.

野崎康明（1992）＜研究プロジェクト総合報告＞教 育・研究におけるコンピューターの活用：III4. 体 育授業におけるコンピューターの活用. 総合文化 研究所紀要/同志社女子大学総合文化研究所, 9: 74-84.

布目寛幸（2001）ITを用いた動きの観察と評価. 体 育の科学, $51: 612-614$.

岡本茂監（1999）パソコン用語事典（99-2000 年版). 技術評論社：東京.

Richards, J.G. (1987) Microcomputer applications in biomechanics. In: Donnelly, J.E. (Ed.) Using microcomputers in physical education and the sport sciences. Human Kinetics: Champaign, pp. 235-262.

Sariscsany, M.J. and Pettigrew, F. (1997) Effectiveness of interactive video instruction on teacher's classroom management declarative knowledge. Journal of Teaching in Physical Education, 16: 229-240.

佐々木真理・チャリン，マングカング (2002) タイ 国へのコンピュー夕教育援助（その8）：日本・夕 イ国際遠隔共同授業「体育」の学習活動に対する 児童の意識の分析およびタイ国児童向け「器械体 操」WBT 型マルチメディア CD-ROM教材の開発. 京都教育大学紀要, 101：77-92.

Silverman, S. (1997) Technology and physical education: present, possibilities, and potential problems. Quest, 49: 306-314.

Steffen, J. and Hansen, G. (1987) Effect of computer- assisted instruction on development of cognitive and psychomotor learning in bowling. Journal of Teaching in Physical Education, 6: 183-191.

Strand, B. and Reeder, S. (1993a) Using heart rate monitors in research on fitness levels of children in physical education. Journal of Teaching in Physical Education, 12: 215-220.

Strand, B. and Reeder, S. (1993b) A comparison of time in the training zone from two independent studies involving middle school students in physical education. Physical Educator, 50: 180-186.

Strand, B. and Mathesius, P. (1995) Physical education with a heartbeat. Part2. Journal of Physical Education, Recreation, and Dance, 66 (9): 64-68.

杉山照美 (1990a) 短距離走の記録測定（中学校, 全 学年, 体育分野「陸上競技」領域). 堀口秀嗣監 FCAI実践シリーズ, 教科編/保健体育. 文溪堂： 東京, pp. 51-63.

杉山照美（1990b）陸上競技の練習方法とルール（中 学校, 全学年, 体育分野「陸上競技」領域). 堀口 秀嗣監 FCAI実践シリーズ, 教科編/保健体育. 文溪堂：東京, pp. 65-71.

高村達夫（1994）パソコンを使った体育授業の実践 例・バスケットボールの授業 (小学校)。体育科教 育, 42 (11)：20-23.

Wilkinson, C. and Hiller, R. (1999) The effects of volleyball software on female junior high school students' volleyball performance. Physical Educator, 56: $202-210$.

山田憲政 · 関岡康雄 - 小林一敏 ·宮下 憲 - 金子靖 仙（1987）コンピュータを用いた三次元運動解析 に関する基礎的研究. 筑波大学体育科学系紀要, 10 : 167-175.

山本博男 · 田中千春 - 園下晶久 ・田中克枝 (2003a) 中学校ハンドボール授業に扮けるチームプレー指 導の CAI 活用. 金沢大学教育学部教育工学研究・ 実践研究, $29: 29-43$.

山本博男・田澤孝治・松田繁樹（2003b）小学校にお けるフラッグフットボール指導の CAI 活用. 金沢 大学教育学部教育工学研究・実践研究, 29 : 4551.

山本朋弘・池田幸彦・清水康敬（2003c）体育「跳び 箱運動」指導における動画コンテンツ活用の効果. 日本教育工学雑誌, $27 ： 153-156$. 
山中邦夫・梁殿乙 (1993) コンピュータによる 1992 ・サッカー・アジアカップにおけるプレーパ ターンに関する記述分析. 筑波大学運動学研究, $9: 57-65$.

山中邦夫 ·上向貫志 ·宇野 努 - 辛島啓珠 - 梁殿 乙・徐金山（1994）コンピュータによる1993・ワ
ールドカップ・アジア最終予選における日本代表 のプレーパターンに関する記述分析. 筑波大学運 動学研究, $10: 39-48$.

(平成 17 年 9 月 29 日受付) 平成 18 年 2 月 18 日受理 